\title{
Arranged Marriage: As an Example of Marginalized Relationships
}

\author{
Dr. Gunjan Agarwal ${ }^{1}$ \& Gunjan Kapil ${ }^{2}$ \\ ${ }^{1}$ Associate Professor (Department Of Humanities) Maharishi Markandeshwar University, Ambala, Haryana, \\ India \\ ${ }^{2}$ Research Scholar (Department Of Humanities) Maharishi Markandeshwar University, Ambala, Haryana, India
}

\section{Introduction}

Chitra Banerjee Divakaruni is one of those enthusiastic personalities who have been indulged in the fruition of the Indo-American literature. Bewilderment by the death of her grandfather, and the entanglement in her grief far from family, were two intensely emotional experiences which induced her to write to preserve memories and sort out her feelings. Divakaruni's investment in women's issues is seen not only in her writings but also in her extra literary activities. In 1991, the author assisted in the Advisory board of "Maitri" in the San Francisco Bay Area and "Daya" in Houston. Both are the organizations that help South Asian or South Asian American women who find themselves in abusive or domestic violence situations.

Fiction by South Asian writers often focuses on relationships and arranged marriages such as Jhumpa Lahiri's novel The Namesake and Arranged Marriage a short story collection by Chitra Banerjee Divakaruni. Arranged Marriage, which won the Before Columbus Foundation American Book Award in 1996 exhibits women's turmoil in the absence of decision-making powers. The Booklist review can also be summed up in praise of the innovative stories as it terms them, "Ravishingly beautiful stories . . . Divakaruni not only conveys emotions with stunning accuracy, she also transforms the outer world into reflections of the soul" (qtd. in AM).

The women in Arranged Marriage are portrayed as strong and willing to change their situations in life but sometimes they do also feel themselves trapped in a myth of wife, mother, and daughter-in-law. Divakaruni herself admits that, "Not in such depth, but I still have to understand my characters and their central conflict and what they want" (Dill n.p.). While Divakaruni's female protagonists are well- rounded and sympathetic, her male characters seem to be stereotype and flat. In an essay entitled "What Women Share" she even goes to the extent of refuting the male portrayal of women characters as depicted in the epics:

But when I did read the epics and other classic texts of Indian culture, I was surprised to find few portrayals of friendships among women. I find myself focusing my writing on friendships with women, and trying to balance them with the conflicting passions and demands that come to us as daughters and wives, lovers and mothers. (Divakaruni)

The relationship of the Indian women to marriage is that one area which defines the complex narrative of gender, migration, ethnicity, and feminism. Oxford Dictionaries define marriage as, "The legally or formally recognized union of a man and a woman (or, in some jurisdictions, two people of the same sex) as partners in a relationship" (OD). One of the most significant, dominant and sacred institutions, marriage occupies a crucial role in Indian society and it plays a decisive role in human relationships too. Portrayal of marriage in Indian novels is a recurrent theme and it is the element in Indian writing in English which gives it a typical Indian sensibility. In this connection Meenakshi Mukherjee observes: "Among some hundred and fifty novels published in the last thirty years, one finds hardly two dozen books where a marriage ceremony has not been described" (qtd. in Rajeshwar \& Piciucco 29).

The marriage plot serves the writers in two different ways: It is a kind of consolation and outlet for their own personal dissatisfactions, and as a mirror to domestic/familial conditions, it becomes almost a detailed document appealing to the demands of realism. Divakaruni's depiction of many of the married protagonists is as if the marriage has become their fait accompli. When asked by Donna Seaman whether, "Marriage and family life are at the heart of your work". Divakaruni answers as:

I think that comes out of my cultural background. Family is central to the traditional Indian upbringing, which is the way I raised. We are taught as children that family is the first thing in your life. You are members of a family first, and then you're an individual. Now having lived in the West for a long time, I don't agree with that completely, but family still remains very, very important to me. (qtd. in Seaman 157)

The idea of arranged marriage evokes images of loveless and choice-less unions in which people, more often women, are enforced into marriage. Regardless of stereotypes, arranged marriages in some form are still the norm in many if not most countries, including India which is often considered the vanguard of arranged 
marriages. As Kathleen Glenister Roberts and Ronald C. Arnett's book entitled Communication Ethics: Between Cosmopolitan and Provinciality, reveals that, "Despite Western influences and popular media images, an estimated $95 \%$ of the marriages in India are still arranged" (qtd. in Roberts \& Arnett 35). The present study depicts the institution of marriage a step further and shows it as a relationship which blocks the individuals or women systematically from opportunities and resources that are normally available to members of a society, or deny their full access to various rights which are fundamental to social integration within a particular society.

In Arranged Marriage Divakaruni has restructured the romantic marriage plot with its grounding in the realistic detail of everyday life, to expose, at times, the incongruity or absurdity of received tradition, and to try and construct a step toward freedom and selfhood. In contemporary times, a large stream of women's narratives has begun to question and chafe at the relevance of traditional values and structures which merely cause and perpetuate women's oppression. The present study comprises of the stories entitled "The Bats", "The Maid Servant's Story", "Silver Pavements Golden Roofs", "The Disappearance" and "A Perfect Life" to fulfill the desired aspect that is to reveal Indian arranged marriage as a marginalized relationship, still unexplored and thus here lays the relevance and importance of the work. The very first story of the collection entitled "The Bats" shows the power struggle between man and woman in a typical traditional manner, which results into an estrangement of their married life. "The Bats", reminiscent of Henry James's What Maisie knew, uses a child narrator to tell the story of her father's abuse of her mother in innocent terms: "Things fell a lot when Father was around, maybe because he was so large" (AM 2). The narrator (the daughter) continues to describe the plight of her mother as, "That year mother cried a lot, nights. Or maybe she had always cried, and that was the first year I was old enough to notice. . . . a yellow blotch with its edges turning purple. It looked like my knee did after I bumped into the chipped mahogany dresser next to our bed last month" (AM 2). Herein story naturalizes the oppression of woman through its stereotypical representation of woman as weak, vulnerable, and an obstacle in man's life. This kind of oppression has also been contested by Simon De Beauvoir in the following terms:

A woman is not born: she becomes, is made a woman. This is to say that the socialization of woman renders her a woman with certain apparently "inherent" qualities- weakness, feeblemindedness, patience and so on. All these help patriarchal males to argue that women need to be confined to the home (they are not strong to "go out" into the world), be protected and controlled. Her sexuality and desires are made and treated as subservient to that of the male's. ... Gendering is a practice of power, where masculinity is always associated with the authority. (qtd. in Nayar 83)

Kate Millett's book entitled Sexual Politics, situated at the crossroads of literary and cultural criticism and political theory, had also launched a major criticism of canonical male authors like Lawrence, Norman Mailer and Henry Miller. She stated that in the works of the male authors violence and coercion have been used "to sustain images/stereotypes so that the male's control over sexuality is never loosened" (qtd in Nayar 88). The image of a brutal male turns into the fraudulence male in "The Maid Servant's Story", where a respectable banker seems to have a loving relationship with his wife, until it is revealed that he tiptoes in the privacy of night to seek a sexual liaison with the wife's maid. "The Maid's Servant's Story", the most complex tale from the narrative point, the protagonist hears of the tragic episode in her mother's life that changed her, which allows her to understand her mother's distance. The story within a story becomes a cautionary tale, as the protagonist thinks:

I wonder if the story (though not intended as such by my aunt) is a warning for me, a preview of my own life which I thought I had fashioned so cleverly, so differently from my mother's, but which is only a repetition, in a different raga, of her tragic song. Perhaps it is like this for all daughters, doomed to choose for ourselves, over and over, the men who have destroyed our mothers. (AM 167)

In this context some recent discussions of marriage has been presented as they assume that "the conjugal relations are purely contractual- husbands and wives contractually acquire for their exclusive use their partner's sexual properties" (qtd. in Pateman 154). The words, occurring at the beginning of Shashi Deshpande's Roots and Shadows that, "Behind the façade of romanticism, sentiment and tradition, what was marriage after all, but two people brought together after cold-blooded bargaining to meet, mate and reproduce so that the generations might continue?" (qtd. in Singh 81), represent a radically changed outlook to the institution of marriage.

Both the stories entitled "The Bats" and "The Maid Servant's Story" are set in India, and the wives portrayed in them are overpowered by the males in their lives, as they are unable to free themselves from their undesirable marriages. The economic dependence of the mother deepens her plight as "Mother had explained. . . . she never had much money, and whenever she asked for any, Father flew into one of his rages" (AM 3). In general it has been said that, "the woman's labour in the house is much more integrated with her life than for the male. Her economic dependency is an important factor, since it deprives her of any political control" (qtd. in Nayar 95). In the book entitled Companion Reader on Violence Against Women, it has also been mentioned that 
the "Studies have consistently identified economic dependence as a critical obstacle for many women who are attempting to leave abusive partners" (qtd. in Renzetti, Dleson \& Bergen 55). Michael P. Johnson depicts the effects of economic dependence of a woman and says that:

Interference with a woman's economic independence, including her ability to work and earn money, can impede her ability to exit a destructive relationship and achieve financial stability after escaping the relationship. In fact, economic dependency and lack of economic resources are among the most common barriers to leaving reported by the battered woman. (qtd. in Johnson n.p.)

Social conditions and cultural traditions perceive that the woman's identity is never separate but is subsumed under that of the male and the social forces continue to stifle the mother. She shrieks out her anguish against this oppression that, "I couldn't stand it, the stares and whispers of the women, down in the market place. The loneliness of being without him" (AM 12). But the forces of the masculinity go on and the father shows his authority over her, which results into her leaving home after every fight. Jacqui True's book The Political Economy of Violence Against Women also argues that, "Though most violence against women is perpetuated by men, it is the gendered social and economic inequalities between women and men that make women most vulnerable to violence; it is women's impoverished situation relative to men that is at the root of violence" (True 5). At the end of the story, Divakaruni paves the way out of the life of exploitation, confusion and struggle, and this way is full of hope, the hope of living further only for the of sake of her daughter. The relationship between mother and daughter is simply complex as the young daughter wonders at her mother's simple belief that her father will change, realizing that her mother "just didn't know the way I did" (AM 14). In the end of both the stories, "The Bats" and "The Maid Servant's Story" the daughters are made to learn how to survive in the male dominated world despite its continual oppressing forces, as Manisha also says, "It's how we survive, we Indian women whose lives are half light and half darkness" (AM 167).

The wives in "The Bats" and "The Maid Servant's Story" surrender to the manipulations of their husbands with little resistance. They stay in their abusive marriages to maintain the sham of social respectability while the cores of their lives are being eroded. But the stories end differently for Indian women who have immigrated to America and are ultimately ready to embrace what Divakaruni characterizes as western values. As in "The Disappearance" the wife is a Calcutta woman who lives in America with her husband and manages to get out of a marriage that she dislikes, due to no apparent reason as the husband sees it, other than the husband's exercising of his normal authority. So the immigrant woman in an uninteresting marriage exercises greater freedom of will than the women who are non-immigrants and stuck in marriages that are far worse. But while Divakaruni sees the failings of Indian patriarchy and Indian men, she mostly fails to notice any flaws in American men and American patriarchy society. In fact, she creates clear binaries between men from "the old countries" (AM 187) and American or Indian-American men. Although there is not any defining idea of Indian womanhood because of various regional classes, linguistic, religious, and ethnic differences, the dominant image is one where the woman is defined in relation to her status (i.e., mother, daughter, or wife) to men and her ability to maintain the home and to bear children. Indian immigrant women often struggle with being the symbolic representative of the homeland and also having to negotiate alternative cultural norms and expectations associated with the women in the United States.

The reflection of radical humanism which is a perspective within feminism that focuses on the hypothesis of patriarchy as a system of power that organizes society into a complex of relationships based on the assertion that male supremacy oppresses women also marks its presence in the story. It was first introduced by Paulite Johnson who in her book entitled Feminism as Radical Humanism (1994) advocates that radical humanism incorporates two interconnected values: the equal value of all people as members of a generic 'humanity', and the value of someone's uniqueness and individuality. Humanist feminists emphasize in their politics that women are ordinary human beings just as men are. As Jean Grimshaw points out in Feminist Philosophers (1986), human nature itself is then seen as something that is the same in men and women.

Modern humanist feminists indicate this same idea with the difference between 'sex' and 'gender'. For instance, Ann Oakley argues in Sex, Gender and Society (1972) that "sex differences may be 'natural' but gender differences have their source in culture, not nature" (qtd. in Voet 90). Thus it has been concluded that the inequality of sexes does not have a biological basis or origin, it originates in the cultural constructions of gender difference. It can be said that instead of presenting the estrangement, Divakaruni gives her characters hope, stability and the power to think over their relations without any confusion and social forces.

As Pauline Johnson's Feminism as Radical Humanism (1994) has sought to resituate feminism within the humanist tradition, she argues against the anti-humanism of contemporary feminism, and says that feminism must see itself as "the interpreter of the cultural ideals of modern humanism. To this end Johnson suggests that humanism must be interpreted as the "value idea of autonomous self-constituted personality. On the other hand, the protagonist of "A Perfect Life" opposes this kind of marriage where the conditions would be of the male only. She declares that: 
Because in Indian marriages becoming a wife was only the prelude to that all-important, allconsuming event- becoming a mother. That wasn't why I'd fought so hard-with my mother to leave India; with my professors to make it through graduate school; with my bosses to establish my career. Not that I was against marriage-or even against having a child. I just wanted to make sure that when it happened, it would be on my own terms, because I wanted it. (AM 77)

Linking the physical and psychological landscapes of India and America, she explores the experiences of women who enact strategies of survival in changing cultural contexts. So is her story entitled "Silver Pavements, Golden Roofs", wherein Divakaruni tries to understand the psyche of the victims of domestic abuse and the gripping forces that keep them locked in an abusive relationship. Jayanti, the protagonist, who goes to the United States as a college student with many dreams which are complicated by her encounter with her immigrant aunt's unsophisticated husband (both of Indian origin) and the racist slur of the neighborhood boys. As the protagonist states, "I've looked forward to this day for so long that when I finally board the plane I can hardly breathe. ... As a child in India, sometimes it is used to sing a song. Will I marry a prince from a far-off magic land, where the pavements are silver and the roofs all gold?" (AM 35).

Jayanti witnesses the compromises her Aunt Pratima has had to make after getting married to Bikramuncle. When Jayanti asks her aunt to go outside, she refuses it saying that, "Your uncle does not like me to go out. He is telling me it is dangerous. "How can it be dangerous?" I say. It's just a ploy of his to keep her shut up in the house and under his control" (AM 46). In Carole Pateman's book entitled The Sexual Contract, "Marriage is called a contract but, feminists have argued, an institution in which one party, the husband, has exercised the power of a slave-owner over his wife and in the 1980s still remains some remnants of that power, is far removed from a contractual relationship" (qtd. in Pateman 154). Jayanti surprises over such wedlock that, “. . . spitefully I wonder how a marriage could take place between a man like Bikram-uncle and my aunt, who comes from an old and wealthy landowning family" (AM 39). In contrast, the fictive white professor Jayanti fantasizes about is drawn as the uncle's polar opposite; he is handsome, refined, and romantic. He is the one Jayanti imagines as a husband, the man with whom she will fall in love when she breaks away from the Indian traditions of arranged marriages as she declares, "No arranged marriage like Aunt's for me!" (AM 45).

In Schouler's A Treatise on the Law of the Domestic Relations it has been suggested that, "we are then to consider marriage, not as a contract in the ordinary acceptation of the term; but as a contract sui generis, if needed it be a contract at all; as an agreement to enter into a solemn relation which imposes its own terms" (qtd. in Pateman 155). In 1888, a judge in the United States stated:

when the contracting parties have entered into the married state, they have not so much entered into a contract as into a new relation, It was of contract that the relation should be established, but, being established, the power of the parties as to its extent or duration is at an end. Their rights under it are determined by the will of the sovereign as evidenced by law. (qtd. in Pateman 156)

\section{Conclusion}

Conclusively it can be stated that the theme of marriage plays the role of a pervasive social institution which causes turbulence and misery in the lives of all the women characters by one way or the other. Divakaruni's feminism causes her to speak against Indian men in various ways in these short stories. Divakaruni seems to delineate the queer compulsions of married life, its irredeemable and invariable monotony, its bondage and restrictions, power imbalances and double standards and the gradual cessation of female identity. Echoing Western feminists like Simone de Beauvoir and Germaine Greer, some of the writers look at marriage as "legalized reproduction" and apprehend the "power politics" which according to Kate Millett operates in marriages in a subtle manner. And yet, marriage is the aim of a woman's life and therefore, the marriage plot continues to be the most appropriate subject matter for women writers even in recent times. Empowering the concept of women's individuality, Divakaruni illustrates in an essay entitled "What Women Share", that:

But ultimately we can be ourselves with each other. Ourselves with all our imperfections. Ourselves uncomplicated by all the emotions that complicate our other relationships: duty, lust, romance, the need to impress or control. We can be women and know that, as women, we are understood. (Divakaruni)

\section{References}

[1]. Dill, L. Margo. “One Amazing Author: Chitra Banerjee Divakaruni.” WOW-WomenonWriting.com 40 (2010): n.pag. Web. 21 Aug. 2014. < http://www.wow-womenonwriting.com/40-Inspiration-ChitraBanerjeeDivakaruni.html $>$

[2]. Divakaruni, Chitra Banerjee. Arranged Marriage. London: The Random House Group Ltd., 1995. Print. Referred to as AM 
[3]. Michael, P. Johnson. A Typology of Domestic Violence: Intimate Terrorism, Violent Resistance, and Situational Couple Violence. Lebanon: Northeastern University Press, 2010. Web. 31 Jul 2014.

[4]. Nayar, Pramod K., Literary Theory Today. New Delhi: Asia Book Club, 2006. Print.

[5]. Pateman, Carole. The Sexual Contract. California: Stanford University Press, 1988. Web. 30 Jul. 2014

[6]. Rajeshwar, Mittapalli, \& Pier Paolo Piciucco, eds. Studies in Indian Writing in English. Atlantic Publishers and Distributors New Delhi, 2000. Web. 30 Jul 2014

[7]. Renzetti, Claire M., \& Jeffrey L. Edleson, Raquel Kennedy Bergen, eds. Companion Reader on Violence Against Women. California: Sage Publications, Inc., 2012. Web. 31 Jul 2014.

[8]. Roberts, Kathleen Glenister, \& Ronald C. Arnett, eds. Communication Ethics: Between Cosmopolitanism and Provinciality. New York: Lang Publishing, Inc., 2008. Web. 26 Jul 2014.

[9]. Seaman, Donna. Writers on the Air: Conversations about Books. Pennsylvania: Paul Dry Books, Inc., 2005. Web. 23 Jul 2014.

[10]. Singh, Chandra Nisha. Radical Feminism and Women's Writing: Only So Far and No Further. New Delhi: Atlantic Publishers \& (P) Ltd., 2007. Web. 25 Jul 2014.

[11]. Tajeshwar, Mittapalli, \& Joel Kuortti, eds. Indian Women's Short Fiction. New Delhi: Atlantic Publishers \& Distributors (P) Ltd. 2007. Print.

[12]. True, Jacqui. The Political Economy of Violence Against Women. New York: Oxford University Press, 2012. Web. 3 Aug. 2014.

[13]. Voet, Maria Christine Bernadetta Rian, \& Rian Voet, eds. Feminism and Citizenship. London: Sage Publications Ltd, 1998. Web. 2 Aug. 2014.

[14]. $\quad$ http://www.businessdictionary.com/definition/marginalization.html $>$

[15]. $\quad<$ http://www.oxforddictionaries.com/definition/english/marriage $>$

[16]. <https://www.randomhouse.com/boldtype/0199/divakaruni/essay.html $>$

[17]. $<$ https://www.youtube.com/watch? $=$ ENpDSmd0BnQ $>$

[18]. < http://www.wow-womenonwriting.com/40-Inspiration-ChitraBanerjeeDivakaruni.html $>$ 